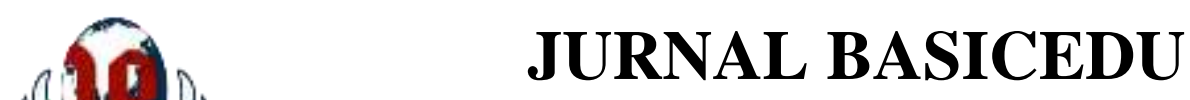

Volume 5 Nomor 6 Tahun 2021 Halaman 5472 - 5480

Research \& Learning in Elementary Education

https://jbasic.org/index.php/basicedu

\title{
Implementasi Pendidikan Kewarganegaraan melalui Nilai Pancasila dalam Menangani Kasus Bullying
}

\author{
Eka Fauziah Pratiwi ${ }^{1 凶}$, Salwa Siti Sa'aadah ${ }^{2}$, Dinie Anggraeni Dewi $^{3}$, \\ Yayang Furi Furnamasari ${ }^{4}$ \\ Pendidikan Guru Sekolah Dasar, Universitas Pendidikan Indonesia, Indonesia ${ }^{2,3,4}$ \\ E-mail: ekafauziahp@ upi.edu ${ }^{1}, \underline{\text { salwassaaadah@upi.edu }}^{2}, \underline{\text { dinieanggraenidewi @edu.id }}^{3}, \underline{\text { furi2 }}$ @10 @ upi.edu ${ }^{4}$
}

\begin{abstract}
Abstrak
Penelitian ini bertujuan untuk mencari tahu serta menganalisis lebih lanjut mengenai bagaimana peran Pendidikan Kewarganegaraan melalui Nilai Pancasila dalam mengatasi kasus bullying yang dilakukan oleh anak sekolah dasar. Penelitian ini dilaksanakan dengan metode kualitatif, yang mana teori atau dasar pembahasannya diperoleh berdasarkan hasil studi literatur dari beberapa sumber seperti jurnal, artikel, dan buku yang tentu berhubungan dengan masalah yang akan dipecahkan. Seperti yang kita ketahui bahwa saat ini perilaku bullying banyak terjadi khususnya pada anak sekolah. Bullying dikatakan sebagai suatu bentuk kekerasan anak (child abuse) yang dilakukan oleh teman seusianya kepada seorang (anak) yang lebih "rendah" atau lebih lemah guna memperoleh keuntungan atau kepuasan tersendiri. Perilaku bullying yang sering terjadi pada anak sekolah dasar yaitu berbentuk verbal, contohnya saling mengejek. Oleh karena itu, Pendidikan Kewarganegaraan di sekolah dasar diharapkan dapat memperbaiki karakter baik pada siswa serta dapat mendorong siswa dalam memahami dan bisa melaksanakan hak-hak juga kewajibannya dalam menjadi warga negara yang baik, cerdas, terampil, dan bertanggung jawab khususnya melalui nilai Pancasila yang banyak mengandung nilai kemanusiaan.
\end{abstract}

Kata Kunci: Pendidikan Kewarganegaraan, Nilai Pancasila, Bullying.

\begin{abstract}
This study aims to find out and further analyze the role of Citizenship Education through Pancasila Values in dealing with bullying cases that occur in elementary school children. This research was conducted using a qualitative method, where the theory or basis of the discussion was obtained based on the results of literature studies from various sources such as journals, articles, and books which of course related to the problem to be solved. As we know that currently bullying behavior occurs a lot, especially in school children. Bullying is a form of violence against children carried out by peers to someone (child) who is 'lower' or weaker to get a certain advantage or satisfaction. Bullying behavior that often occurs in elementary school children is verbal, for example mocking each other. Therefore, Citizenship Education in elementary schools is expected to shape the character of students and can encourage students to understand and be able to carry out their rights and obligations to become good, intelligent, skilled, and responsible citizens, especially through the values of Pancasila that contain many values of humanity.
\end{abstract}

Keywords: Citizenship Education, Pancasila Values, Bullying.

Copyright (c) 2021 Eka Fauziah Pratiwi, Salwa Siti Sa'aadah, Dinie Anggraeni Dewi, Yayang Furi Furnamasari

Corresponding author :

Email : ekafauziahp@upi.edu

DOI : https://doi.org/10.31004/basicedu.v5i6.1648

ISSN 2580-3735 (Media Cetak)

ISSN 2580-1147 (Media Online) 
5473 Implementasi Pendidikan Kewarganegaraan melalui Nilai Pancasila dalam Menangani Kasus Bullying - Eka Fauziah Pratiwi, Salwa Siti Sa'aadah, Dinie Anggraeni Dewi, Yayang Furi Furnamasari

DOI: https://doi.org/10.31004/basicedu.v5i6.1648

\section{PENDAHULUAN}

Pendidikan mempunyai andil yang sangat penting dalam membentuk kepribadian pada seseorang. Pendidikan juga diakui sebagai sebuah komponen yang sangat berpengaruh terhadap majunya sebuah bangsa dan negara. Oleh sebab itu pendidikan menjadi prioritas utama yang dikembangkan oleh suatu bangsa. Pada Undang-Undang Nomor 20 Tahun 2003 mengenai Sistem Pendidikan Nasional Pasal 1 Ayat 1 termuat isi bahwasanya pendidikan sebagai sebuah usaha sadar serta terstruktur guna menciptakan suasana belajar serta kegiatan pembelajaran agar potensi yang dimiliki peserta didik dengan aktif mampu dikembangkan sehingga dapat memiliki kekuatan spiritual, religius, intelektual, pengendalian diri, kepribadian, akhlak yang baik, serta keterampilan yang diperlukan dirinya, masyarakat, bangsa bahkan negara. Dari pernyataan tersebut maka bisa diambil sebuah makna yaitu pada hakikatnya pendidikan merupakan sebuah proses dalam membantu generasi muda agar memiliki kecerdasan, memiliki karakter dan moral yang baik, berilmu dan bertaqwa, serta dapat mengembangkan potensi yang dimilikinya.

Pemerintah Indonesia memiliki program yang mewajibkan warga negaranya untuk berpendidikan minimal 12 tahun yang dimulai sejak sekolah dasar. Pendidikan dasar merupakan sebuah pondasi awal sebelum melanjutkan jenjang pendidikan selanjutnya. Sekolah dasar yang menjadi wadah dalam proses pendidikan dasar diharapkan dapat menumbuhkan karakter dan akhlak baik pada peserta didik. Menurut (Annisa, Wiliah, \& Rahmawati, n.d.), proses pendidikan karakter perlu dilaksanakan sedari kecil dan dapat dimaksimalkan dalam usia sekolah. Maka, guru memiliki peran yang penting dalam menciptakan proses pendidikan yang efektif dan menyenangkan bagi siswa agar proses pendidikan dapat terlaksana sesuai dengan tujuannya.

Dalam proses belajar mengajar, termuat cukup banyak mata pelajaran yang telah disesuaikan dengan kebutuhan siswa. Salah satu pelajaran yang penting diajarkan pada siswa sekolah dasar adalah Pendidikan Kewarganegaraan. Pendidikan Kewarganegaraan (PKn) memiliki sebuah tujuan yang istimewa ialah untuk melahirkan warga negara yang baik (good citizen) dalam rangka nation and character building (Giwangsa, 2018). Dalam Pendidikan Kewarganegaraan ini mengandung banyak nilai moral yang berasaskan pada nilai dasar negara serta nilai Pancasila yang dapat membentuk karakter baik pada siswa. Pendidikan Kewarganegaraan juga memiliki misi yaitu untuk meningkatkan potensi yang dimiliki anak, menyiapkan anak untuk hidup di tengah masyarakat, serta membentuk budaya kewarganegaraan sebagai salah satu penentu bagi kehidupan yang bersifat demokratis.

Di tengah perkembangan zaman yang semakin pesat, karakter tiap peserta didik tentu mengalami perubahan bahkan penyimpangan. Salah satu penyimpangan yang masih banyak ditemui pada siswa sekolah dasar adalah perilaku agresif yang dapat menyebabkan kebiasaan untuk membully temannya. Kata bullying bermula dari Bahasa Inggris, yakni dalam kata bull dengan arti banteng yang suka merunduk ke berbagai arah. Berdasarkan etimologi dalam Bahasa Indonesia, kata bully memiliki arti menggertak atau orang yang suka mengusik orang lain yang lemah. Sedangkan berdasarkan terminologi definisi bullying menurut Ken Rigby (Zakiyah, Humaedi, \& Santoso, 2017) ialah suatu keinginan untuk menyakiti yang ditunjukan ke dalam tindakan, sehingga membuat orang lain menderita. Tindakan ini dilakukan secara spontan oleh seseorang bahkan sekelompok orang yang lebih berkuasa, tidak bertanggung jawab, dan biasanya terjadi dengan berulang, serta merasa senang ketika melakukannya. Budaya bullying (kekerasan) dengan mengatasnamakan senioritas masih terus terjadi pada anak Sekolah Dasar, sering kali tindakan bullying terulang terus menerus, bahkan ada yang dilakukan secara terus berulang kali (Usmaedi, Sapriya, \& Mualimah, 2021).

Dalam kurun waktu 9 tahun, yaitu dari tahun 2011 hingga tahun 2019, KPAI mencatat bahwa pengaduan kekerasan terhadap anak ini mencapai 37.381 kasus. Kekerasan itu merupakan tindakan bullying baik dalam pendidikan maupun di dalam media sosial, yang mencapai angka 2.473 laporan dan hingga kini 
5474 Implementasi Pendidikan Kewarganegaraan melalui Nilai Pancasila dalam Menangani Kasus Bullying - Eka Fauziah Pratiwi, Salwa Siti Sa'aadah, Dinie Anggraeni Dewi, Yayang Furi Furnamasari

DOI: https://doi.org/10.31004/basicedu.v5i6.1648

terus meningkat (Tim KPAI, 2020). Kasus bullying yang sempat hangat menjadi perbincangan terjadi pada tahun 2017. Kasus bullying ini mengakibatkan korban sampai bunuh diri karena tidak tahan menerima tindak kekerasan yang dilakukan oleh teman-temannya. Lalu pada awal bulan Oktober 2021, terjadi kasus bullying yang menimpa seorang siswa kelas 5 SD di Sumatera Selatan. Menurut berita yang ditulis oleh (Pratama \& Nugraha, 2021), korban yang berusia 12 tahun diduga mengalami bullying yang dilakukan oleh dua orang kakak kelas serta seorang adik kelasnya. Korban mengalami patah pada bagian leher dan sempat koma hingga dua hari. Kasus ini masih diselidiki oleh pihak sekolah dan dinas pendidikan setempat.

Mengingat masih banyaknya kasus bullying yang terjadi di Indonesia, kita sebagai pendidik tentu harus berperan aktif dalam membantu mengatasi permasalahan ini. Seorang guru atau tenaga pendidik memiliki peran yang cukup penting dalam mengatasi penyimpangan yang terjadi pada peserta didik. Maka dari itu, penelitian ini dibuat agar bisa menjadi referensi bagi tenaga pendidik dalam mengatasi perilaku bullying dengan mengajarkan Pendidikan Kewarganegaraan melalui penanaman nilai-nilai yang ada pada Pancasila. Karakter baik diharapkan dapat terbentuk melalui penanaman nilai moral yang terkandung dalam Pendidikan Kewarganegaraan. Guru harus bisa mengatasi perilaku bullying karena jika hal tersebut dibiarkan maka dapat berdampak buruk terhadap perkembangan siswa, terutama bagi korban. Pada hakikatnya seorang guru merupakan pendidik yang harus mampu mengembangkan potensi dasar yang dimiliki oleh peserta didik dengan optimal agar dapat melahirkan sebuah suasana kelas yang terarah dalam kegiatan belajar mengajar yang aman serta nyaman, membimbing siswa agar bisa membentuk korelasi yang baik, menghindari perselisihan, serta permasalahan pada dunia pendidikan (Dewi, 2020).

\section{METODE}

Penelitian kali ini menggunakan metode studi literatur dengan jenis penelitian kualitatif deskriptif. Metode studi literatur merupakan metode yang berusaha untuk menggambarkan keadaan atau fenomena berdasarkan pengumpulan data serta kajian pustaka dari berbagai sumber seperti artikel, jurnal, buku, dan sumber-sumber lain yang dapat dipertanggungjawabkan. Salah satu artikel rujukan yang kami gunakan adalah artikel yang dibuat oleh Usmaedi, Sapriya, dan Mualimah pada tahun 2021 dengan judul "Optimalisasi Pendidikan Kewarganegaraan dalam Mengatasi Perilaku Bullying Siswa Sekolah Dasar”. Artikel tersebut kami pilih karena isinya memuat hal-hal yang dapat menjadi referensi bagi artikel yang akan kami buat serta artikel tersebut memiliki reputasi yang baik karena sudah dipublikasikan dijurnal yang terakrediatasi. Menurut (Gunawan, 2013), metode kualitatif ini berdasarkan pada sifat fenomenologis yang berusaha mengungkapkan atau menafsirkan makna dari suatu peristiwa interaksi tingkah laku manusia dalam kondisi tertentu. Data-data kualitatif yang telah dikumpulkan kemudian dijabarkan secara deskriptif dalam membahas artikel ini yang menyoroti bagaimana cara mengimplementasikan Pendidikan Kewarganegaraan dengan menanamkan nilai-nilai Pancasila guna mengatasi permasalahan bullying.

\section{HASIL DAN PEMBAHASAN}

Setelah peneliti melakukan pengkajian terhadap beberapa sumber yang telah didapatkan, peneliti menemukan bahwa saat ini kasus bullying yang terjadi semakin banyak dan khususnya terjadi pada anak sekolah. Bullying di sekolah kini telah menjadi masalah global yang terjadi dimana-mana. Menurut Komisi Perlindungan Anak (dalam Amnda et al., 2020), Indonesia termasuk kedalam negara yang memiliki pelaporan masyarakat mengenai kasus bullying terbanyak. Kasus perilaku bullying ini memiliki beberapa kategori yaitu diantaranya, pelaku, korban, serta seorang atau sekelompok penonton. Dari ketiga kategori tersebut semuanya memiliki keterikatan. Bullying biasanya disebabkan karena seorang pelaku bullying tumbuh dalam keluarga 
5475 Implementasi Pendidikan Kewarganegaraan melalui Nilai Pancasila dalam Menangani Kasus Bullying - Eka Fauziah Pratiwi, Salwa Siti Sa'aadah, Dinie Anggraeni Dewi, Yayang Furi Furnamasari

DOI: https://doi.org/10.31004/basicedu.v5i6.1648

yang memiliki masalah, stress, atau bahkan anak tersebut memiliki trauma dalam hidupnya. Tentunya lingkunganlah yang menjadi pengaruh utama dalam membentuk kepribadian anak dan dapat membuatnya memiliki pribadi yang mudah emosi dan sulit untuk mengendalikannya.

Menurut ( Dewi, 2020), perilaku bullying terbagi kedalam berbagai bentuk, dengan tingkatan yang beda. Bentuk-bentuk bullying tersebut diantaranya yaitu berupa bullying fisik, bullying verbal, dan bullying non verbal atau tidak langsung. Contoh dari bullying fisik seperti nonjok, mendorong, memukul, menendang, dan juga menggigit. Bullying fisik ini biasanya menimbulkan luka fisik seperti lecet, memar bahkan yang paling fatal itu adalah kematian. Contoh bullying yang berbentuk verbal diantaranya menyoraki, memberikan sindiran, mengolok-olok, memberi hinaan, dan memberi ancaman. Sementara itu bullying tidak langsung antara lain berbentuk memberikan pandangan yang sinis, cuek dan mengabaikan, menyebarkan gosip, serta memerintah orang lain untuk menyakiti. (N. Dewi, Hasan, \& AR, 2016) juga mengatakan dimana merusak barang atau hasil karya orang lain, mencuri barang berharga, dan meminta uang secara paksa pun juga termasuk kedalam tindakan bullying.

Perilaku bullying yang banyak terjadi pada sekolah dasar diantaranya yaitu perilaku bullying yang berbentuk verbal seperti halnya mengejek atau menghina temannya dan bahkan memanggil dengan sebutan nama orang tuanya. Hal tersebut juga selaras dengan hasil dari penelitian yang dilakukan (Hertinjung, 2013)H, yang menunjukkan bahwa berdasarkan dari pihak pelaku bullying, bullying yang paling sering dilakukan ialah bullying yang berbentuk verbal, kemudian urutan kedua yang paling sering terjadi yaitu bullying non verbal dan yang paling jarang itu bullying berbentuk fisik. Selain itu bisa juga dilihat dari sudut pandang korban yang hasilnya yaitu bentuk bullying yang paling sering ialah bullying verbal, kemudian bullying fisik, dan yang terakhir yaitu bullying nonverbal. Antara sudut pandang pelaku dan sudut pandang korban bullying di sekolah dasar tersebut memiliki kesamaan bahwa bentuk bullying verbal ini menjadi kasus yang paling sering terjadi. Hal ini dapat disebabkan karena pelaku bullying menganggap bahwa perilaku seperti itu merupakan hal biasa atau hanya untuk bercanda dan bukan termasuk perilaku bullying.

Perilaku siswa di sekolah yang bersifat bullying tidak bisa dipungkiri kini banyak terjadi dengan tanpa disadari oleh guru maupun siswanya itu sendiri. Namun dikarenakan adanya pandemi Covid-19 yang mengakibatkan siswa harus belajar secara online di rumah, maka kasus bullying mengalami penurunan. Tetapi tidak dapat dipungkiri bahwa kasus bullying masih terus terjadi di lingkungan rumah tempat siswa bermain. Terlebih saat ini beberapa sekolah dasar di Indonesia sudah mulai menerapkan kembali pembelajaran langsung secara tatap muka. Tentunya hal ini harus menjadi perhatian bagi tenaga pendidik maupun orang tua siswa agar kasus bullying tidak mengalami peningkatan lagi.

Untuk mengatasi atau meminimalisir perilaku bullying yang terjadi pada siswa sekolah dasar ini tentu gurulah yang memiliki peran sangat penting dalam mendidik anak agar tidak melakukan hal-hal yang termasuk ke dalam perilaku bullying. Hal tersebut dikarenakan seorang guru itu tidak hanya memiliki tanggung jawab dalam hal nilai akademis saja, melainkan seorang guru juga harus mempunyai sebuah tanggung jawab guna membentuk karakter serta tingkah laku yang baik terhadap para siswanya. Dalam kasus bullying siswa yang terjadi di lingkungan sekolah ini, guru memiliki hak untuk secepatnya melakukan sebuah tindakan dalam mengatasi perilaku bullying agar perilaku bullying dapat berkurang dan anak terhindar dari terjadinya berbagai macam kekerasan yang membahayakan anak. Selaras dengan pesan dalam UndangUndang Republik Indonesia Nomor 23 Tahun 2002 yang berisi tentang Perlindungan Anak Pasal 4 yang bunyinya, "Setiap anak mempunyai hak hidup, tumbuh, berkembang, juga berpartisipasi dengan lazim sesuai harkat serta martabat kemanusiaan, dan juga menerima perlindungan dari berbagai kekerasan dan diskriminasi" (Mandiri, 2017). Sebagai guru dalam membentuk pribadi dan karakter anak yang baik dapat diimplementasikan dalam proses pembelajaran melalui beberapa mata pelajaran yang berkesinambungan. 
5476 Implementasi Pendidikan Kewarganegaraan melalui Nilai Pancasila dalam Menangani Kasus Bullying - Eka Fauziah Pratiwi, Salwa Siti Sa'aadah, Dinie Anggraeni Dewi, Yayang Furi Furnamasari

DOI: https://doi.org/10.31004/basicedu.v5i6.1648

Dalam kasus bullying, Pendidikan Kewarganegaraan dapat menjadi sebuah solusi. Hal ini karena Pendidikan Kewarganegaraan memiliki tujuan dalam mencetak generasi muda agar terbentuk menjadi masyarakat yang baik, cinta tanah air, bertanggung jawab dan siap untuk hidup ditengah masyarakat serta kehidupannya di masa yang akan datang sesuai dengan Pancasila dan juga UUD 1945. (Putri, 2021.) menjelaskan pengertian Pendidikan Kewarganegaraan secara etimologi yakni berdasarkan pemaknaan kata pendidikan dan kewarganegaraan, dimana pendidikan yaitu usaha dan proses dalam mengembangkan kemampuan serta potensi yang dimiliki secara sadar sedangkan kewarganegaraan yakni semua hal yang berkaitan dengan warga negara, hukum, dan juga politik. Pendidikan Kewarganegaraan alias civic education merupakan sebuah program belajar yang secara khusus berusaha untuk memanusiakan (humanizing) serta membudayakan (civilizing) dan juga memberdayakan (empowering) manusia atau peserta didik (diri serta kehidupannya) untuk melahirkan warga negara yang baik yang selaras dengan ketentuan konstitusional bangsa dan negara.

Dasim Budimansyah ( dalam Akbal, 2016 ) menjelaskan visi Pendidikan Kewarganegaraan secara filosofis mempunyai visi holistik-eklektis yang menggabungkan secara cocok dengan pandangan perenialisme, esensialisme, progresivisme, serta sosio rekonstruksionisme dalam latar belakang keIndonesiaan. Secara sosio politik juga kultural pendidikan kewarganegaraan ini mempunyai visi yaitu ingin mencerdaskan kehidupan bangsa dan menumbuh kembangkan kecerdasan kewarganegaraan (civic intelligence). Kecerdasan kewarganegaraan ini menjadi syarat dalam pembangunan demokrasi untuk arti yang luas, yang menjadi tuntutan dalam mewujudkan kebudayaan kewarganegaraan atau civic culture sebagai salah satu penentu dalam tumbuh dan berkembangnya sebuah negara demokrasi. Pendidikan Kewarganegaraan juga memiliki misi yaitu untuk meningkatkan sebuah potensi yang dimiliki anak, menyiapkan anak untuk hidup ditengah masyarakat, serta membentuk budaya kewarganegaraan sebagai salah satu penentu bagi kehidupan yang bersifat demokratis. Selain itu (Retnasari \& Hidayah, 2019) mengatakan bahwa Pendidikan kewarganegaraan memiliki dalam konteks operasioal guna membentuk generasi muda yang memiliki landasan wawasan kebangsaan.

Pendidikan Kewarganegaraan dalam mengatasi masalah bullying pada anak sekolah dasar ini dapat diimplementasikan melalui nilai Pancasila, sebab seperti yang kita tahu bahwasanya Pancasila ini merupakan sebuah pedoman atau pandangan hidup yang dapat digunakan oleh masyarakat Indonesia. Pancasila dapat dikatakan sebagai sebuah ideologi dasar bagi bangsa Indonesia. Pancasila berdasar kepada bahasa sansekerta yakni "Panca" yang berarti 5 serta "Sila" yang memiliki arti prinsip maupun asas. Selain itu kata sila berawal dari kata susila, yang artinya sikap yang baik. Maka menurut kebahasaan bisa dikatakan bahwa Pancasila itu dikatakan sebagai lima batu sendi atau dasar atau bisa juga diartikan sebagai lima sikap atau tingkah laku yang baik (Gultom, 2019). Fungsi pokok dari pancasila yaitu sebagai pedoman hidup bangsa Indonesia, sebagai akar dari segala sumber hukum, sebagai sebuah perjanjian luhur, dan sebagai falsafah hidup negara Indonesia (Gesmi \& Hendri, 2018 ).

Setiap nilai yang terkandung dalam Sila Pancasila tentu memiliki makna, seperti dalam Sila pertama yaitu "Ketuhanan yang Maha Esa" memiliki makna bahwa Indonesia berlandaskan agama. Sila kedua "Kemanusiaan Yang Adil dan Beradab" mengandung nilai kemanusiaan untuk menjunjung tinggi sebuah keadilan serta martabat manusia yang merupakan makhluk ciptaan Tuhan, yang diaktualisasikan dalam semangat saling menghargai, toleran, dimana tingkah laku sehari-hari dipusatkan kepada nilai-nilai moral yang luhur, dan demi kepentingan bersama. Sila Ketiga "Persatuan Indonesia" mengandung makna Indonesia yang memiliki beragam suku serta budaya diharapkan tetap mampu menjalin keharmonisan. Sila Keempat "Kerakyatan yang Dipimpin oleh Hikmat Kebijaksanaan dalam Permusyawaratan/Perwakilan" mengandung makna bahwa Indonesia merupakan negara yang bersifat demokratis. Sila Kelima "Keadilan Sosial bagi 
5477 Implementasi Pendidikan Kewarganegaraan melalui Nilai Pancasila dalam Menangani Kasus Bullying - Eka Fauziah Pratiwi, Salwa Siti Sa'aadah, Dinie Anggraeni Dewi, Yayang Furi Furnamasari

DOI: https://doi.org/10.31004/basicedu.v5i6.1648

Seluruh Rakyat Indonesia" mengandung makna bahwa masyarakat Indonesia diperlakukan sama tanpa melihat perbedaan (Octavian, 2018).

Menurut (Asmaroini, 2016), Pancasila mempunyai rangkaian nilai, diantaranya nilai religius, humanistik, persatuan, kerakyatan, serta keadilan. Nilai- nilai Pancasila ini bisa digunakan untuk sebuah landasan dasar dan juga motivasi dalam segala tindakan yang bernilai baik didalam kehidupan sehari-hari juga dalam bentuk kenegaraan (Pratiwi, Eka Fauziah \& Anggraeni, 2021). Nilai-nilai dasar Pancasila tersebut bersifat universal, objektif, maknanya nilai-nilai tersebut bisa digunakan dan dibenarkan oleh negara- negara lainnya. Kemudian Pancasila bersifat subjektif, memiliki arti bahwa nilai-nilai Pancasila itu terpaku kepada pemicu dan penunjang nilai Pancasila itu sendiri, yakni masyarakat, bangsa, dan negara Indonesia. Nilai-nilai Pancasila juga berperan sebagai pandangan hidup bagi bangsa Indonesia. Oleh karena itu dalam mencegah dan menangani perilaku bullying pada siswa sekolah dasar bisa dilakukan dengan mengajarkan anak tentang nilai-nilai yang terkandung dalam sila Pancasila, diantaranya:

1. Ketuhanan Yang Maha Esa

Dalam sila pertama ini terkandung nilai bahwa kita itu sebagai makhluk ciptaan Tuhan memiliki derajat yang sama. Meskipun Indonesia memiliki 5 agama beda dan diakui, hal itu bukan berarti dapat menjadi perbedaan. Keberagaman sudah seharusnya tidak bersifat hierarkis, tetapi egaliter, dengan demikian berimplikasi dalam nilai etis toleransi. Sebagai umat yang beragama dan beriman serta bertakwa kepada Tuhan, sudah sewajarnya kita memiliki nilai- nilai kebenaran, kebaikan, kejujuran,serta kemuliaan dalam diri, sehingga dapat memajukan moral bangsa (Octavian, 2018).

Melalui sila pertama ini, kita sebagai guru dapat menerangkan kepada siswa bahwa peran kita sebagai makhluk ciptaan Tuhan haruslah saling menghargai. Kita tidak boleh berlaku kasar kepada sesama makhluk hidup, sehingga tidak ada orang yang tersakiti. Siswa juga perlu diberi bekal pengetahuan tentang rasa saling menyayangi yang diajarkan oleh agama. Hal ini diharapkan dapat mencegah serta meminimalisir perilaku bullying yang terjadi pada siswa sekolah dasar.

2. Kemanusiaan Yang Adil Dan Beradab

Sila kedua ini memiliki nilai yang menjunjung tinggi kemanusiaan. Kemanusiaan yang dimaksud disini yaitu manusia yang adil juga beradab, menjunjung tinggi nilai-nilai keadilan serta martabat manusia sebagai makhluk Tuhan, yang diciptakan dalam semangat untuk saling menghargai, toleran dalam perilaku sehari-hari didasarkan pada nilai-nilai moral yang tinggi, dan untuk kepentingan bersama. Dalam hal ini, kita sebagai pendidik dapat mengajarkan siswa untuk berperilaku baik terhadap sesama. Kita sebagai manusia harus bisa berlaku adil serta tidak boleh memperlakukan orang lain dengan berbeda.

3. Persatuan Indonesia

Dalam sila ketiga ini terkandung nilai yang berarti bahwa kita sebagai warga negara Indonesia haruslah bersatu meskipun terdapat banyak perbedaan diantara kita. Sila ketiga juga mengajarkan kita untuk hidup saling membantu dan gotong-royong. Negara Indonesia merupakan negara yang memiliki banyak keragaman tapi tetap satu, mengikatkan diri dalam persatuan yang digambarkan dalam semboyan negara kita yaitu Bhinneka Tunggal Ika. Perbedaan tidak seharusnya menjadi masalah serta menyebabkan permusuhan, melainkan untuk diarahkan pada suatu yang dapat saling menguntungkan yaitu persatuan dalam kehidupan bersama guna menciptakan tujuan bersama (Antari \& De Liska, 2020).

Persatuan pada sila ketiga sangat erat kaitannya dengan perilaku yang dapat merujuk pada sebuah persahabatan. Ketika siswa paham apa makna dari persatuan ini, mereka pastinya akan saling menghargai dan berteman dengan siapapun. Persahabatan yang terbentuk antara siswa tentunya dapat mengurangi bahkan mencegah perilaku bullying. Mereka akan bersatu dan menciptakan suasana yang hangat serta menyenangkan dalam pertemanannya. 
5478 Implementasi Pendidikan Kewarganegaraan melalui Nilai Pancasila dalam Menangani Kasus Bullying - Eka Fauziah Pratiwi, Salwa Siti Sa'aadah, Dinie Anggraeni Dewi, Yayang Furi Furnamasari

DOI: https://doi.org/10.31004/basicedu.v5i6.1648

4. Kerakyatan Yang Dipimpin Oleh Hikmat Kebijaksanaan Dalam Permusyawaratan/Perwakilan

Sila keempat mengajarkan kita untuk hidup dengan bermusyawarah. Musyawarah yang terjadi dapat membentuk sikap demokratis. Siswa diharapkan dapat bersikap demokratis dan bisa menghargai perbedaan pendapat dengan temannya. Jika siswa paham akan makna demokrasi ini, tentunya perilaku bullying terhadap perbedaan pendapat tidak akan terjadi diantara mereka. Sehingga, siswa dapat hidup rukun dan saling menghargai perbedaan yang terdapat diantara mereka.

5. Keadilan Sosial Bagi Seluruh Rakyat Indonesia

Dalam sila kelima ini terkandung nilai keadilan. Disini anak dapat diajarkan untuk bersikap adil kepada semua orang diantaranya yaitu tidak membeda bedakan teman sehingga anak bisa berteman dengan siapapun dan tidak memberikan perlakuan yang berbeda kepada setiap temannya. Dengan demikian tentu sila kelima dalam pancasila ini dapat membantu dalam membentuk karakter yang baik kepada siswa dan tentunya dapat membantu untuk meminimalisir kasus atau perilaku bullying yang terjadi pada anak.

Dapat dilihat dari nilai nilai pancasila diatas bahwa begitu banyak nilai kemanusiaan dalam pancasila yang dapat membentuk karakter yang baik kepada siswa. Nilai pancasila dianggap memiliki peran penting dan sangat berpengaruh untuk membangun karakter positif terhadap generasi muda, hal tersebut dikarenakan di dalam pendidikan pancasila tertuang nilai nilai yang dapat membangun kepribadian generasi muda khususnya terhadap generasi muda indonesia. Sebagaimana yang disebutkan (Fitriani \& Dewi, 2021) bahwa eksistensi Pancasila dalam kehidupan berbangsa dan bernegara keberadaannya sangat diperlukan, karena nilai pancasila bisa berperan sebagai benteng pelindung untuk menumbuhkan kembali karakter bangsa yang luntur dalam menghadapi dampak arus globalisasi bagi generasi penerus bangsa Indonesia. Selain itu ilai-nilai yang terkandung pada setiap sila Pancasila merupakan wujud dari karakter bangsa Indonesia sebagai cerminan warga negara yang baik Good Citizen. Oleh karena itu tentunya sebagai bangsa Indonesia yang berideologikan Pancasila hendaknya kita dapat menanamkan nilai-nilai Pancasila dalam membentuk karakter penerus bangsa dalam berkehidupan berbangsa dan bernegara sehingga terbentuk karakter masyarakat bangsa Indonesia yang seharusnya. Dalam mengimplementasikan nilai nilai pancasila ini tentunya diharapkan siswa dapat mengetahui aturan aturan yang baik dalam berteman dan bermasyarakat serta memiliki akhlak yang baik sehingga perilaku bullying dapat teratasi sedikit demi sedikit.

\section{KESIMPULAN}

Bullying dapat dikatakan sebagai satu bentuk kekerasan pada anak yang dilakukan oleh salah satu atau sekelompok teman seusianya kepada seseorang anak yang lebih lemah untuk menghasilkan keuntungan atau kepuasan tersendiri bagi seorang pelakunya. Perilaku bullying terbagi kedalam beberapa bentuk, dengan tingkatan yang beda. Bentuk-bentuk bullying tersebut diantaranya yaitu berupa bullying fisik, bullying verbal, dan bullying non verbal atau tidak langsung. Perilaku bullying yang sering terjadi pada sekolah dasar yaitu perilaku bullying yang berbentuk verbal seperti mengejek/menghina temannya dan bahkan memanggil dengan sebutan nama orang tuanya. Untuk meminimalisir perilaku bullying tersebut tentunya guru memiliki peran yang sangat penting dalam membentuk karakter baik pada anak. Pendidikan karakter tersebut dapat diimplementasikan melalui Pendidikan Kewarganegaraan karena sesuai dengan tujuannya yaitu untuk membentuk generasi muda agar menjadi masyarakat yang baik, cinta tanah air, bertanggungjawab dan siap untuk hidup ditengah masyarakat. Pendidikan Kewarganegaraan dalam mengatasi perilaku bullying pada anak sekolah dasar ini kemudian dapat diimplementasikan melalui nilai-nilai pancasila yang mengandung banyak 
5479 Implementasi Pendidikan Kewarganegaraan melalui Nilai Pancasila dalam Menangani Kasus Bullying - Eka Fauziah Pratiwi, Salwa Siti Sa'aadah, Dinie Anggraeni Dewi, Yayang Furi Furnamasari

DOI: https://doi.org/10.31004/basicedu.v5i6.1648

nilai kemanusiaan. Sebagaimana pernyataan (Saaadah \& Dewi, 2021) yang mengatakan bahwa pancasila dapat dijadikan sebagai salah satu bentuk upaya untuk memperkuat karakter baik pada anak.

\section{DAFTAR PUSTAKA}

Akbal, M. (2016). Pendidikan Kewarganegaraan Dalam Pembangunan Karakter Bangsa. Gadjah Mada University Press Bekerjasama Dengan LAN RI., 1(1), 485-493.

Amnda, V., Wulandari, S., Wulandari, S., Nabila Syah, S., Andi Restari, Y., Atikah, S., ... Arifin, Z. (2020). Bentuk Dan Dampak Perilaku Bullying Terhadap Peserta Didik. Jurnal Kepemimpinan Dan Pengurusan Sekolah, 5(1), 19-32. Https://Doi.Org/10.34125/Kp.V5i1.454

Annisa, M. N., Wiliah, A., \& Rahmawati, N. (N.D.). Pentingnya Pendidikan Karakter Pada Anak Sekolah Dasar Di Zaman Serba Digital. BINTANG, 2(1), 35-48.

Antari, L. P. S., \& De Liska, L. (N.D.). Implementasi Nilai Nilai Pancasila Dalam Penguatan Karakter Bangsa. Widyadari: Jurnal Pendidikan, 21(2), 676-687.

Asmaroini, A. P. (2016). Implementasi Nilai-Nilai Pancasila Bagi Siswa Di Era Globalisasi. Citizenship Jurnal Pancasila Dan Kewarganegaraan, 4(2), 440. Https://Doi.Org/10.25273/Citizenship.V4i2.1077

Dewi, Putu Y. A. (2020). Perilaku School Bullying Pada Siswa Sekolah Dasar. Edukasi: Jurnal Pendidikan Dasar, 1(1), 39-48.

Dewi, N., Hasan, H., \& AR, M. (2016). Perilaku Bullying Yang Terjadi Di SD Negeri Unggul Lampeuneurut Aceh Besar. Jurnal Ilmiah Pendidikan Guru Sekolah Dasar, 1(2), 37-45.

Fitriani, R., \& Dewi, D. A. (2021). Membangun Karakter Generasi Muda Melalui Implementasi Nilai-Nilai Pancasila Di Tengah Arus Globalisasi. Edukatif: Jurnal Ilmu Pendidikan, 3(2), 514-522. Https://Doi.Org/10.31004/Edukatif.V3i2.367

Gesmi, I., \& Hendri, Y. (N.D.). Buku Ajar Pendidikan Pancasila. Sidoarjo: Uwais Inspirasi Indonesia.

Giwangsa, S. F. (2018). Pentingnya Pendidikan Moral Dalam Pendidikan Kewarganegaraan. Madrosatuna : Jurnal Pendidikan Guru Madrasah Ibtidaiyah. Https://Doi.Org/10.47971/Mjpgmi.V1i1.16

Gultom, A. (2019). Implementasi Pancasila Dalam Menjaga Eksistensi Bangsa, 30(1), 55-66.

Gunawan, L. (2013). Metode Penelitian Kualitatif. Jakarta: Bumi Aksara.

Hertinjung, W. S. (2013). Bentuk-Bentuk Perilaku Bullying Di Sekolah Dasar. Seminar Nasional Psikologi UMS 2013 - Parenting, 53(9), 450-458. Retrieved From Https://Publikasiilmiah.Ums.Ac.Id/Handle/11617/3952

Mandiri, J. A. (2017). Peran Guru Dalam Mengatasi Perilaku Bullying Pada Siswa Kelas Atas Di SD Muhammadiyah 6 Surakarta.

Octavian, W. A. (2018). Urgensi Memahami Dan Mengimplementasikan Nilai-Nilai Pancasila Dalam Kehidupan Sehari-Hari Sebagai Sebuah Bangsa. Bhinneka Tunggal Ika, 5(2), 123-128.

Pratama, W., \& A, N. (N.D.). Dibully Kakak Kelas, Siswa SD Di Mura 2 Hari Koma Di Rumah Sakit”. Retrieved From Https://Kumparan.Com/Urbanid/Dibully-Kakak-Kelas-Siswa-Sd-Di-Mura-2-HariKoma-Di-Rumah-Sakit-1wiiiu9i7we/Full,

Pratiwi, Eka Fauziah \& Anggraeni, D. (2021). Urgensi Memahami Dan Mengimplementasikan Nilai Pancasila Di Era Globalisasi Dalam Membentuk Krakter Anak Bangsa. Kontruksi Sosial, 1(7), 1-7.

Putri, V. K. M. (N.D.). Hakikat Dan Latar Belakang Pentingnya Pendidikan Kewarganegaraan.

Retnasari, L., \& Hidayah, Y. (2019). Menumbuhkan Sikap Nasionalisme Warga Negara Muda Di Era Globalisasi Melalui Pendidikan Kewarganegaraan Di Perguruan Tinggi (Studi Pada Mahasiswa PGSD 
5480 Implementasi Pendidikan Kewarganegaraan melalui Nilai Pancasila dalam Menangani Kasus Bullying - Eka Fauziah Pratiwi, Salwa Siti Sa'aadah, Dinie Anggraeni Dewi, Yayang Furi Furnamasari

DOI: https://doi.org/10.31004/basicedu.v5i6.1648

UAD). Jurnal Basicedu, 4(1), 79-88. Https://Doi.Org/10.31004/Basicedu.V4i1.303

Saaadah, S. S., \& Dewi, D. A. (N.D.). Implementasi Nilai Pancasila Melalui Pendidikan Bagi Generasi Milenial. Kontruksi Sosial, 1(11), 1-7.

Usmaedi, U., Sapriya, S., \& Mualimah, N. (N.D.). Optimalisasi Pendidikan Kewarganegaraan Dalam Mengatasi Perilaku Bullying Siswa Sekolah Dasar.

Zakiyah, E. Z., Humaedi, S., \& Santoso, M. B. (2017). Faktor Yang Mempengaruhi Remaja Dalam Melakukan Bullying. Prosiding Penelitian Dan Pengabdian Kepada Masyarakat, 4(2), 324-330. 